\title{
Genotypic effects of honey bee (Apis mellifera) defensive behavior at the individual and colony levels: the relationship of guarding, pursuing and stinging
}

\author{
Ernesto GuZMÁn-NovoA a,c*, Greg J. HunT ${ }^{\mathrm{b}}$, José L. URIBE-RUBiO ${ }^{\mathrm{a}, \mathrm{c}}$, \\ Daniel PRIETO-MERLOS ${ }^{\mathrm{c}}$
}

\author{
a INIFAP, Santa Cruz 29B Fracc., Las Hdas., Metepéc 52140, Méx, Mexico \\ b Department of Entomology, Purdue University, West Lafayette IN 47907-1158, USA \\ ${ }^{c}$ Depto. Esp. no Tradicionales: Abejas. Fac. Med. Vet. y Zoot., UNAM. Ciudad Universitaria, 04510, México, \\ DF, Mexico
}

(Received 9 April 2003; revised 4 June 2003; accepted 19 June 2003)

\begin{abstract}
We analyzed the relationships of the guarding, stinging, pursuing and alarm pheromone responses of two types of bees: European (EHB) and Africanized honey bees (AHB). Single type (source colonies) and two-type (EHB and AHB co-fostered) colonies were used. Of co-fostered bees, AHB comprised $81 \%$ of those that stung during the first $10 \mathrm{~s}$. But from 10 to $30 \mathrm{~s}$, AHB and EHB were equally likely to sting. However, when tested in their own colonies, two of the three EHB types did not sting and did not pursue in any of the eight trials conducted, whereas all three AHB types did in all trials. Moreover, AHB represented $90 \%$ of bees that stung observers during an 18-day observation period $(25 \%$ of which were recently seen guarding). There was a relationship between pursuing and stinging of the six source colonies and the guarding behavior of co-fostered individuals from those sources. Results suggest that the more defensive bee types guard longer and may affect the thresholds of response of less defensive bees, recruiting them to sting. Results also suggest that the individual performance of different defensive tasks cause interactions that result in increased colony response.
\end{abstract}

Apis mellifera / genotypic effects / guarding behavior / Africanized bees / defensive behavior

\section{INTRODUCTION}

Social insects have evolved different strategies in nest defense. Some of these strategies involve mass attacks in response to disturbance of the nest. The stimuli that can elicit honey bee stinging include alarm pheromones, visual cues such as rapid motion near the nest, strong vibrations and olfactory cues (Free, 1961; Ghent and Gary, 1962). Honey bees (Apis mellifera $\mathrm{L}$.) that perform guarding tasks (inspecting incoming bees, excluding individuals that do not belong to their colony, and alerting other colony workers about intruders) may have a role in recruiting workers to sting by release of alarm pheromones and visual cues. At the very least, guards can recruit other workers to exit the colony in an agitated state (Butler and Free, 1952; Ribbands, 1954; Maschwitz, 1964). But the precise role of guards is difficult to determine. Whether there is a division of labor between the tasks of guarding and stinging in a honey bee colony has not been clearly demonstrated. It also is unclear how bees of different genotypes interact in a defensive response. For example, do pools of workers that are inherently more likely to sting because of their genotype become depleted after multiple stinging responses or do they also recruit their nestmates to sting?

\footnotetext{
* Corresponding author: guzmane@inifap2.inifap.conacyt.mx
} 
Africanized honey bees (AHB) are much more likely to sting than European honey bees (EHB) and often respond in greater numbers (Collins et al., 1982; reviewed by Winston, 1992). There is a large genetic component to the difference in defensive behavior exhibited by these two types of bees (Collins et al., 1988; Collins and Rinderer, 1991; Stort and Gonçalves, 1991; Hunt et al., 1998). However, there is only one study that has demonstrated that co-fostered AHB and EHB differ in individual stinging behavior (Guzmán-Novoa and Page, 1994). We do not find descriptions of the guarding activities of AHB or the role of guards in defense. Guzmán-Novoa and Page (1994) established colonies containing equal mixtures of EHB and AHB/EHB hybrids. In these colonies, hybrids were more likely to be among those that stung during 1 min of stinging activity. But Guzmán-Novoa and Page (1994) also reported that EHB were more likely to sting in colonies in which they were co-fostered with hybrids than they were in colonies containing only EHB. Perhaps the increased likelihood of EHB to sting when cofostered with hybrids was the result of recruitment by the hybrids, due to behavioral dominance. Behavioral dominance may occur if an individual that has a low threshold of response to a specific stimulus performs a behavior elicited by the stimulus, thereby altering the probability that less sensitive individuals would perform that behavior (Page and Robinson, 1991). Therefore, workers with lower thresholds of response (AHB) to a defensive stimulus are expected to be the first to sting, and their actions may influence the behavior of nestmates through visual and pheromonal stimuli.

The defensive behavioral phenotype of AHB is genetically dominant at the colony level because colonies containing hybrids are as defensive as AHB (Guzmán-Novoa et al., 2002). Dominance for high-defensive behavior at the level of the individual behavior is also a possibility, because a quantitative trait locus, sting-1, which influences whole-colony-level stinging response could only be confirmed to influence individual behavior in backcrosses to the low-defensive EHB parental stock. Guards and individuals that stung were more likely to have African-derived alleles for sting-1 in comparison to random sam- ples of bees (Hunt et al., 1998; GuzmánNovoa et al., 2002). Detecting gene effects only in one backcross is the pattern of results that would be expected for a dominant trait. Alleles at sting- 1 also were found to have a significant association with individual stinging behavior when the first small group of individuals (from one family) to sting a target were assayed for their sting- 1 genotypes, but not in assays of individuals that stung after these first responders (Guzmán-Novoa et al., 2002; and unpublished data). The fact that genetic effects were not observed in the later responders is another indication that recruitment of less defensive genotypes within a colony may play a significant role in colony stinging response.

Genes influencing an individual bee's stinging behavior may also affect guarding activities. Individual duration in guarding of co-fostered EHB correlated with the defensiveness of the colony from which the bee originated: workers from more defensive colonies guarded for longer periods when co-fostered with workers from gentle colonies (Breed et al., 1988; Breed and Rogers, 1991). In addition, at least one gene that was mapped as sting- 1 and was shown to influence colony stinging response also influenced both individual stinging and guarding tasks (GuzmánNovoa et al., 2002). Previous results have indicated that guards and stingers may be genetically and behaviorally distinct groups, but the evidence was not sufficient to resolve the issue of whether a clear division of labor existed for these activities (Breed et al., 1990).

In this study, we assayed the stinging behavior of co-fostered AHB and EHB during two phases of the stinging response as a way to assess the importance of genetic effects and interactions between individuals within colonies. We also tested for relationships between individual guarding of co-fostered bees and their stinging and pursuing tasks, and compared the behavior of co-fostered bees to the defensive behavior of colonies from which they were derived.

\section{MATERIALS AND METHODS}

Two studies were conducted. The first study was conducted to investigate guarding, stinging and 
pursuing responses of co-fostered AHB and EHB. Four relatively small colonies (of 5000 bees) were established that had mixed age distributions to approximate a typical colony age structure. Three unrelated source colonies were used for each of the two types (AHB and EHB), each containing an open-mated queen. We used open-mated queens to provide a broad sample of genotypes so that general inferences about the two types of bees could be drawn. The second study involved a series of defensive behavior assays of the six source colonies to correlate the individual behaviors of co-fostered bees with whole-colony stinging, pursuing and alarm responses.

\subsection{Sources of bees}

For all the experiments, we obtained AHB stocks from swarms captured near our study area at the Center for Beekeeping Development, located near Villa Guerrero, Mexico $\left(19^{\circ} \mathrm{N}, 99^{\circ} \mathrm{W}\right)$. The AHB sources were analyzed morphometrically (Sylvester and Rinderer, 1987) and behaviorally (GuzmánNovoa and Page, 1993) to insure they had African characteristics, and also genetically for the mitochondrial DNA type of A. m. scutellata (Nielsen et al., 1999). We chose three AHB colonies (hereafter referred to as families 1, 2 and 3). We also used naturally mated queens of European origin that were obtained from Glenn Apiaries of Fallbrook CA., USA (family 4) and from a breeding program in Ontario, Canada (families 5 and 6).

\subsection{Study 1: Guarding, stinging and pursuing tasks of co-fostered AHB and EHB}

Two colonies of 5000 bees for each of two mixtures of $\mathrm{AHB}$ to $\mathrm{EHB}$ were established: $25 \%$ $\mathrm{AHB} / 75 \% \mathrm{EHB}$ and $50 \% \mathrm{AHB} / 50 \% \mathrm{EHB}$ to study the effect of the defensive genotype on the gentle one, under similar and under different proportions. All of these colonies were given two frames of brood and two frames of pollen plus nectar, and a mated queen unrelated to the experimental bees. To obtain marked bees from the six families (three AHB and three EHB), frames of brood were placed in screen cages inside of hives of European bees that were unrelated to the source colonies. Incubators were not used in this study because significant preeclosion effects on defensive behavior are unlikely (Moritz et al., 1987). Newly-emerged bees were marked each morning for seven days to allow us to distinguish the six families. Bees were marked on the back of the thorax with colored enamel paint according to the source colony for that genotype. Colonies were established from November 16 to 22, 2000. We introduced 1998 marked bees (333 were counted from each of the six source colonies) into colonies 1 and 2 . These colonies were also initiated with 3000 unmarked bees (equal proportions from the six source colonies measured by volume). In addition, these unmarked bees were older adults so that the colonies would have typical age distributions (consisting of equal mixtures of bees collected from outer combs plus foragers trapped from the colony entrance). Colonies 3 and 4 had about $25 \%$ AHB. These colonies were initiated with about 1000 marked bees (274 AHB and 726 EHB, with the six families proportionally represented) and 4000 unmarked.

The colonies entrances were observed on 18 separate days for at least one half hour per day over a 25-day period and were also checked periodically during each day for any marked individuals that were guarding (guarding propensity). Marked bees that were observed guarding were tagged with numbers so that they were individually identifiable. Guards were briefly chilled on ice in $15 \mathrm{ml}$ plastic tubes until immobile. Then, a numbered plastic tag was affixed to the back of the thorax (Graze KG, Weinstadt, Germany). The number of days each individual guarded was recorded (guarding duration).

Colonies were tested for stinging responses one day after all observations of guarding were finished. We waived a "flag" consisting of a black suede leather patch (see Guzmán-Novoa et al., 1999) $10 \mathrm{~cm}$ above the top of the frames. After $10 \mathrm{~s}$ of flag agitation (several bees stung during this period of time), the first flag was placed in a plastic bag with the attached bees and another flag was immediately presented for 20 more s by another manipulator and then placed in a bag. We designed this test with two asymmetric periods, to capture the most responsive bees by not allowing too much time for them to sting during the first phase of the test, whereas for the second phase we allowed more time for bees with higher thresholds of response to sting. Flags were waved below a net $(40 \mathrm{~cm}$ diameter) that was intended to capture those bees that stung the patch and then detached from it. The colors of marked bees captured in this way were recorded. The observers then retreated $5 \mathrm{~m}$ and netted bees that had pursued them and were flying around them, to record their colors (only those bees that did not sting but pursued were recorded). We also determined the relative likelihood of bees to appear in each category of the test for each of the six families in the mixedgenotype colonies. This was done using the same procedure to calculate relative propensity to guard (by dividing their proportion within a task group by their proportion in the hive). In addition, the occasional stings received from marked bees in the clothes or skin of observers during 18 days of observations of guarding activities were recorded. 


\subsection{Study 2: Relationship between individual guarding and colony defensive behavior}

The six colonies (containing approximately 30000 bees each) that were used as sources of bees to make the mixed-genotype colonies in study 1 were tested eight times each with the following assays of defensive behavior so that individual defensive behavior could be correlated with colonylevel behavior. The colonies were manipulated to make them equal in colony population two weeks before the tests by removing brood and bees from the stronger colonies. Only one assay was performed on each colony in the course of a day to allow time for the bees to become calm again. The colonies were tested for response to alarm pheromone by placing a filter paper with $5 \mu \mathrm{l}$ of an alarm pheromone component (Isopentyl acetate or IPA) in the colony entrance. The number of bees before presentation of IPA and $20 \mathrm{~s}$ after was recorded in photographs. The source colonies were also tested for stinging responses using the same flag test described above, by waving a black suede flag above the brood frames for $20 \mathrm{~s}$. After termination of the test for stinging response, the observers (three) walked slowly to a distance of $25 \mathrm{~m}$ from the hive. At this distance, the number of bees flying around the operators was estimated. Each operator counted the number of bees flying around the operator next to him. The figures were summed and an average was obtained. In another assay, we tested how quickly bees would respond by waiving a leather flag $5 \mathrm{~cm}$ in front of a colony and recording the time it took bees to deposit the first sting on the leather.

\subsection{Statistical analyses}

Data for numbers of individuals of various genotypes that were stinging or pursuing were analyzed by Chi-square tests for goodness-of-fit to the expected values based on the expected proportion of each genotype in the colony. If a homogeneity Chi-square showed no differences between the two colonies within a treatment, then the Chi-square was calculated based on summed data from colonies within a treatment (that contained equal proportions of AHB to EHB). Mean ranks were calculated from Kruskal-Wallis tests for individual guarding duration of the six families measured in days and for the weighted daily number of guards of co-fostered bees. We compared the mean ranks with the rankings from the defensive behavior assays of the source colonies to determine which whole-colony defensivebehavior traits best correlated with the behaviors of individuals.
Average relative likelihood to pursue or sting was calculated by taking the proportion of individuals performing a defensive task represented by a given family, correcting for representation of that family within the colony, and averaging across colonies, so that a " 1 " would indicate the expected proportion. This was done to correct for differences in numbers of marked bees between families and colonies. For example, the adjusted number of bees $(N)$ for a hypothetical family $\mathrm{X}$ was calculated for colony $\mathrm{Y}$ according to the formula:

$$
\begin{aligned}
N= & (S)\left(\text { average } \mathrm{I}_{\mathrm{Y} \text { families }} / I_{\text {family }} \mathrm{X}\right) \\
& \times\left(\text { total average } \mathrm{I}_{\text {all colonies }} / \text { total } I_{\text {colony } \mathrm{Y}}\right)
\end{aligned}
$$

where $S$ is the number of stingers observed for the family $X, I$ is the number of marked bees introduced and $I$ is the average number of marked bees introduced of all families.

\section{RESULTS}

\subsection{Study 1: Guarding, stinging and pursuing tasks of co-fostered AHB and EHB}

We found that AHB were more likely to sting than EHB at the beginning of a defensive response, and in situations having a low stimulus for defensive behavior. Stinging assays in small colonies involved collecting the first five to ten individuals that stung during $10 \mathrm{~s}$ of waiving the suede leather patch (the flag) over the frames of the open hive, followed by collecting those that stung in the next $20 \mathrm{~s}$. Most $(81 \%)$ of the first bees to sting the patch were AHB (Chi-Square test: $\mathrm{X}^{2}{ }_{1}=11.84, P<0.001$ and $\mathrm{X}^{2}{ }_{1}=9.31, P<0.01$ for colonies containing $25 \%$ and $50 \%$ AHB, respectively; see Fig. 1). But the representation of AHB and EHB among those that stung during the subsequent 10 to $30 \mathrm{~s}$ period was not different from their representation in the hive (Chi-Square test: $\mathrm{X}^{2}{ }_{1}=2.27$ and $0.69, P>0.05$, for colonies containing $25 \%$ and $50 \% \mathrm{AHB}$, respectively, Fig. 1).

The European family 4 was similar to AHB family 1 for being among the first to sting and to pursue in these colonies (Fig. 2). AHB family 1 had bees that stung more rapidly. Eleven $(52 \%)$ of the first responders were from family 1 even though these were only about $16.7 \%$ of the marked bees in the 50\%-AHB colonies and 


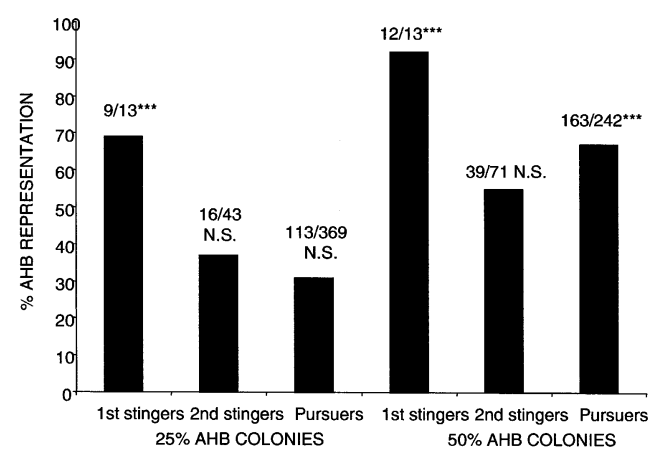

Figure 1. Percentage Africanized bees performing defensive tasks in four small colonies of mixed Africanized/European (AHB/EHB) families. Colonies contained either $25 \%$ or $50 \%$ AHB. The numbers above each bar represent the number of AHB/ total number of bees stinging or pursuing in five repetitions of a defensive assay. The first individuals to sting a leather patch (1st stingers) were collected in $10 \mathrm{~s}$ of stinging activity, whereas the remaining stingers (2nd stingers) were collected during the 20 subsequent s. Pursuing bees were netted at $5 \mathrm{~m}$ from the tested colonies (Chi-Square tests, $* * * P<0.001$; N.S., $P>0.05)$. Sources were derived from six open-mated queens, either AHB (families 1, 2 and 3) or EHB (families 4, 5 and 6).

only about $9 \%$ of the bees in $25 \%$-AHB colonies. The two types of bees (AHB and EHB) were equally represented among those that stung in the second period. No tagged EHB guards stung during this test but six tagged AHB did. Each of these six bees had been observed guarding the day before the test was conducted. When the sting test was over, AHB were over-represented among bees that pursued observers for a distance of $5 \mathrm{~m}$ in three of the four hives. Some tagged AHB (12) and EHB (8) pursued the observers.

Marked worker bees from the co-fostered colonies sometimes stung the observers during the 18 days of observations. Since these were occasional stings by individual bees and we tried to move slowly to avoid being stung, there was a low stimulus for eliciting defensive behavior. Of the 29 marked bees that stung the observers, $26(90 \%)$ were AHB. Nineteen of these individuals $(66 \%)$ were from family 1 . Five of these family 1 individuals had been tagged as guards and one each of families 2 and 3 AHB responders had been also tagged as guards. One of the three EHB

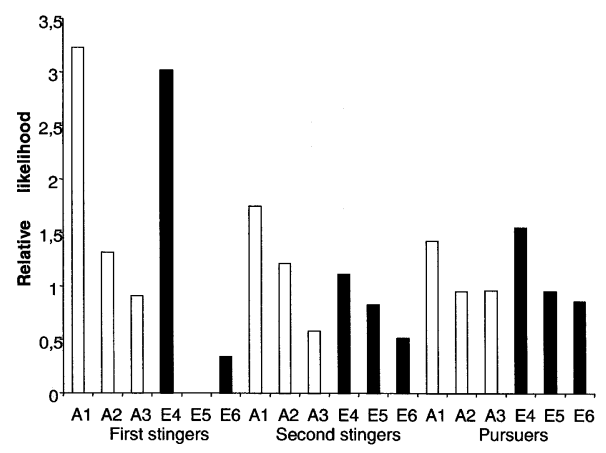

Figure 2. Relative propensity to sting during first $10 \mathrm{~s}$ and second $20 \mathrm{~s}$ periods, and relative likelihood to pursue $5 \mathrm{~m}$ for six families of bees co-fostered in small colonies. Average relative propensities were calculated by taking the proportion of responders represented by a given source, correcting for its representation within the colony, and averaging across colonies, so that a " 1 " would indicate the expected proportion. Sources were derived from six open-mated queens, either AHB (families A1, A2 and A3) or EHB (families E4, E5 and E6). Task groups are described in Figure 1.

that stung had also been tagged as guard (from family 5). The other two EHB that stung were from family 4 . All of the tagged AHB had been actively guarding during the day that they stung, or within the two-day period before stinging.

\subsection{Study 2: Relationship between individual guarding and colony defensive behavior}

We found significant differences between genotypes (families) for guarding duration, and the daily number of guards (propensity), when measured as the adjusted number of guards seen each day (Kruskal-Wallis tests, $\mathrm{H}=23.33$ and $\mathrm{H}=45.64, \mathrm{df}=5, P=0.0008$ and $P<0.0001$, respectively, Tab. I). The defensiveness of the six source colonies also differed in the assays (Tab. I). The three AHB source colonies were all more defensive than EHB colonies and family 4 EHB source colony was more defensive than the other two EHB colonies. A relationship was found between source colony defensiveness and the guarding duration of individuals from these sources observed in study 1 , but not with guarding propensity. The mean ranks for 
Table I. Average results of defensive behavior assays of the source colonies and guarding propensity and duration of individual bees in co-fostered colonies ${ }^{\mathrm{a}}$.

\begin{tabular}{|c|c|c|c|c|c|c|}
\hline \multirow[b]{2}{*}{ Family } & \multicolumn{2}{|c|}{ Behavior of individual co-fostered bees } & \multicolumn{4}{|c|}{ Average response of the source colonies } \\
\hline & $\begin{array}{l}\text { Mean daily number of } \\
\text { guards (mean rank) }^{\mathrm{b}}\end{array}$ & $\begin{array}{l}\text { Mean number of days for indi- } \\
\text { vidual guarding (mean rank) }\end{array}$ & $\begin{array}{l}\text { No. of } \\
\text { stings }\end{array}$ & $\begin{array}{c}\text { No. of } \\
\text { pursuers }\end{array}$ & $\begin{array}{l}\text { Time to } \\
\text { sting }^{f}\end{array}$ & $\begin{array}{l}\text { Response to alarm } \\
\text { pheromoneg }\end{array}$ \\
\hline $1(\mathrm{AHB})$ & $4.2(274)$ & $5.1(157)$ & 98 & 47 & 1.2 & 244 \\
\hline $2(\mathrm{AHB})$ & $2.5(226)$ & $4.7(145)$ & 45 & 43 & 1.7 & 139 \\
\hline $3(\mathrm{AHB})$ & $1.5(167)$ & $4.3(147)$ & 45 & 43 & 1.7 & 139 \\
\hline 4 (EHB) & $1.8(177)$ & $3.5(121)$ & 44 & 6 & 7.1 & 150 \\
\hline 5 (EHB) & $1.3(167)$ & $2.5(113)$ & 0 & 1 & 41.6 & 40 \\
\hline $6(\mathrm{EHB})$ & $2.3(216)$ & $3.0(104)$ & 0 & 0 & 17.5 & 29 \\
\hline
\end{tabular}

${ }^{a}$ Colonies were tested eight times each. 1, 2 and 3 are AHB sources. 4, 5 and 6 are EHB sources. Data from individual bees comes from the co-fostered colonies of study 1 .

b Mean adjusted daily number of guards (ranks from Kruskal-Wallis test) in a co-fostered environment. Number of guards was adjusted for differences in numbers of individuals introduced.

$c$ Mean number of days that individuals guarded (ranks from Kruskal-Wallis test) in a co-fostered environment.

Number of guards was adjusted for differences in numbers of individuals introduced.

$\mathrm{d}$ Number of stings in leather flag in $20 \mathrm{~s}$ in source colonies.

e Number of bees that pursued researchers $25 \mathrm{~m}$ after sting test in source colonies.

$\mathrm{f}$ Time (s) until the first sting was deposited in a leather flag waived at the entrance of source colonies.

$\mathrm{g}$ Number of bees remaining on landing board $18 \mathrm{~s}$ after presenting alarm pheromone in the entrance of source colonies.

guarding duration in the co-fostered colonies corresponded to the ranking for number of stings, speed of reaction (s) and also to numbers of pursuers and alarm responders in the source colonies (Tab. I). AHB family 1 was the most likely to guard and had the highest proportion of bees guarding for more than one day. The family 1 source colony gave the greatest responses in terms of speed of reaction (s), numbers of stings, number of pursuers and number of bees responding to alarm pheromone. This correlation of individual and colony-level behavior was also observed for EHB. Family 4 EHB were similar to AHB for duration in guarding. Family 4 was also among the most likely to be guarding at any time compared to other EHB. In addition, bees from source-colony 4 were the only EHB that stung a flag presented directly above the brood frames of an open colony (Tab. I).

\section{DISCUSSION}

Our study expands on earlier results that showed a connection between individual guarding duration and colony defensive behav- ior, and extends this connection to the behavior of AHB. It was previously shown that individual guarding duration of EHB correlates with the colony response to alarm pheromone, measured as number of bees recruited from a hive (Breed et al., 1988; Breed and Rogers, 1991). Breed and Rogers (1991) found that $87 \%$ of high-defensive EHB were observed to guard for only one day compared with $92 \%$ of low-defensive EHB. In the present study, the relationship between individual guarding and other colony behaviors involved in colony defense was evident between the two types of bees (AHB and EHB) and also between families within each type. Family 1 had the workers that guarded the longest and originated from the colony that had the fastest stingers, gave the most stings, the most pursuers, and the most responders to IPA. Family 4 EHB had bees with the longest duration in guarding among the EHB and also gave the highest measures of defensiveness among the EHB source colonies for all assays of defensive behavior. In addition, two of the three EHB that stung observers in the course of study 1 were from family 4, and this family was second only to AHB family 1 in propensity to 
sting and pursue when co-fostered with the other 5 sources (Fig. 2).

After partitioning the stinging response of co-fostered bees into two periods, the first $10 \mathrm{~s}$ and later stinging activity, it was evident that AHB responded much more rapidly than EHB. Fast responses by AHB were also evident in source colonies, where AHB were 8.2 times faster to sting than EHB (Tab. I). But after the first few stings were deposited (in co-fostered colonies), AHB and EHB were equally represented amongst those stinging. These results could explain why earlier studies of ours failed to show a difference in tendency to sting of co-fostered EHB and AHB. But Guzmán-Novoa and Page (1994) did find genotypic effects in propensity to sting between co-fostered EHB and hybrids (AHB/EHB). Hybrids were individually less likely to sting when co-fostered with equal proportions of EHB than they were in their own colonies. Conversely, the co-fostered EHB were more likely to sting in colonies containing hybrids than in their natal nest (Guzmán-Novoa and Page, 1994).

The most likely hypothesis that could explain our results is that the defensive-genotype bees recruit others by means of visual cues and alarm pheromone but there may be additional means by which they influence the response thresholds of nestmates (see Paxton et al., 1994). It is much less likely that the less defensive EHB were simply slower to respond because no bees stung for two of the three EHB source colonies, even in eight repetitions of the assays. The large source colonies were given $10 \mathrm{~s}$ less to sting because large colonies give many more stings than small colonies and in a shorter period of time. In addition, one of these two EHB families whose source colony gave no stings had 3 individuals co-fostered in two different colonies that stung within the first $10 \mathrm{~s}$. The responsiveness of family $4 \mathrm{EHB}$ in relation to AHB also appeared to be altered when co-fostered with AHB because family 4 individuals were more likely to sting and pursue than two of the three AHB families in the five stinging assays involving the co-fostered colonies. However, some differences in behavior between the small-population colonies and the large source colonies could have been caused by differences in age distribution which can influence stinging responses, even though we attempted to have typical age distributions in the small colonies (Giray et al., 2000).

Our results indicate that in the initial phase of the stinging response and under low-stimulus conditions there were large differences between genotypes to respond. The additional observation that $90 \%$ of the bees that stung the observers were AHB during the course of 18 days of observing the small colonies supports the view that AHB have a lower response threshold than EHB to multiple stimuli (visual, olfactory, tactile and pheromonal) for the task of stinging (Free, 1961; Lecomte, 1963; Collins et al., 1982; Collins et al., 1987).

We found that most bees that stung in the small-colony assays had been guarding the day before those assays began. These results do not corroborate the view that a division of labor exists in honey bee defensive behavior in which guards are a genetically distinct group from that of bees that respond by stinging (Breed et al., 1990). One difference between our studies (besides the presence of AHB individuals) and the study of Breed et al. (1990) is that we included observations in which there was a low stimulus to respond. Perhaps only under these low-stimulus conditions or in the initial phase of the stinging response does it become apparent that guards sting readily. For example, $27.6 \%$ of the bees that stung us during observations of the small colonies had recently been seen guarding, even though we saw an average of just eight to twenty guards per colony each day in the four colonies containing 5000 workers $(0.16$ to $0.4 \%$ of the colony population).

Our data suggest that the defensive response of bees can be characterized as a rapid response by individuals that are exposed to the stimulus and are the most genetically predisposed to sting, which includes guards or individuals that had recently been guards, and that these individuals may increase the level of defensive stimuli, thus recruiting less predisposed bees to respond. An alternative hypothesis is that EHB are just slower to respond. However, this explanation is highly unlikely, for reasons already given. Recruitment is probably achieved through both alarm pheromone components and visual cues (flying out). Visual cues are probably most important, given the speed of recruitment. In addition, alarm pheromone components probably provide little 
information for locating a target (Wager and Breed, 2000; but see Picket et al., 1982). Individuals that are recruited may consist of those that are old enough to fly but forage less often than other bees, because bees that stung in several studies of EHB had wings that were less worn on average than the wings of foragers (Breed et al., 1990; Cunard and Breed, 1998). The recent finding that a quantitative trait locus that influences colony stinging response also influences an individual's likelihood to be a guard and to sting shows that at least one gene has an influence on individual guarding, stinging and colony-level stinging responses (Hunt et al., 1998; Guzmán-Novoa et al., 2002). Further studies are needed to quantify interactions between AHB and EHB genotypes that modify response thresholds for stinging responses.

\section{ACKNOWLEDGEMENTS}

We thank Angelica Gris for help in collecting behavioral data. This research benefited by the support of INIFAP and the State of Mexico, which established the Center for Beekeeping Research and Development. Partial support was provided by UNAM (Universidad Nacional Autonoma de México). This research was supported by grants from NSF (IBN-0110842) and the USDA (NRI 35302-10137). The authors also acknowledge useful ideas derived from interaction with the Santa Fe Institute Social Insect Working Group. This paper is dedicated to Eligio Castellanos-Bustos who died of bee stings in 2001 .

Résumé - Effets génotypiques du comportement de défense de l'Abeille domestique (Apis mellifera) aux niveaux individuel et de la colonie : relation entre les comportements de gardiennage, de poursuite et de piqûre. Nous avons analysé les relations de gardiennage, de poursuite et de piqûre et de réaction à la phéromone d'alarme chez deux types d'abeilles: les abeilles européennes (EHB) et les africanisées (AHB). La première étude a étudié les réactions de gardiennage, de poursuite et de piqûre d'AHB et d'EHB regroupées dans une même colonie (co-élevées). On a constitué des colonies (5000 abeilles) avec des EHB et des AHB. Trois colonies sources non apparentées ont été utilisées pour chaque type d'abeilles. Des abeilles naissantes ont été marquées avec une peinture au vernis colorée à raison d'une couleur par colonie source. Les individus marqués qui étaient gardiennes à l'entrée de la ruche ont reçu un numéro qui permettait de les identifier individuellement. On a enregistré le nombre de jours durant lesquels chaque individu avait une activité de gardiennage. Les réactions de piqûre des colonies ont été aussi testées. Pour cela nous avons agité un morceau de cuir noir au-dessus des cadres. Après $10 \mathrm{~s}$ d'agitation (plusieurs abeilles ont piqué durant ce laps de temps), le morceau de cuir a été placé dans un sac plastique avec les abeilles qui s'y étaient accrochées et un autre morceau a été immédiatement présenté pendant 20 autres s. Les couleurs des abeilles ainsi capturées ont été enregistrées. Les expérimentateurs se sont alors reculés de $5 \mathrm{~m}$ et ont capturé dans un filet les abeilles qui les poursuivaient et volaient autour d'eux afin de noter leur couleur.

La seconde étude comportait des tests sur le comportement de défense de six colonies sources pour mettre en corrélation les comportements individuels des abeilles co-élevées avec les réactions de l'ensemble de la colonie. La réponse de la colonie à la phéromone d'alarme a été testée en plaçant de l'acétate d'isopentyle (IPA) à l'entrée de la colonie. Le nombre d'abeilles avant la présence d'IPA et $20 \mathrm{~s}$ après a été enregistré sous forme de photographies. On a aussi testé la vitesse avec laquelle les abeilles réagissaient et piquaient le morceau de cuir agité devant l'entrée de la colonie. Parmi les abeilles co-élevées, les AHB représentaient $81 \%$ de celles qui piquaient durant les 10 premières $\mathrm{s}$. Mais, entre 10 et $30 \mathrm{~s}$, les AHB et les EHB étaient également susceptibles de piquer (Figs. 1 et 2). Pourtant, lorsqu'on les testait dans leur propre colonie, deux des trois types d'EHB ne piquaient et ne poursuivaient dans aucun des huit essais, tandis que les trois types d'AHB le faisaient dans tous les essais (Tab. I). En outre les abeilles AHB représentaient $90 \%$ des abeilles qui avaient piqué les expérimentateurs au cours d'une période d'observation de $18 \mathrm{j}$ ( $25 \%$ d'entre elles avaient été récemment gardiennes). Il y avait une relation entre la réaction de poursuite et de piqûre des six colonies sources et le comportement de gardiennage des individus co-élevés provenant de ces colonies sources (Tab. I). Les résultats suggèrent que les abeilles les plus défensives sont plus longtemps gardiennes et peuvent influer sur les seuils de réaction des abeilles moins défensives en les recrutant pour piquer. Les résultats suggèrent aussi que la performance individuelle des différentes tâches de défense provoquent des interactions qui résultent en une réaction accrue de la colonie.

Apis mellifera / effet du génotype / comportement de défense / comportement de gardiennage / abeille africanisée

\footnotetext{
Zusammenfassung - Genotypische Effekte von Honigbienen (Apis mellifera) im Verteidigungsverhalten auf der individuellen und auf der Volksebene: Das Verhältnis von Wächterdienst, Verfolgung und Stechen. Wir analysierten das Verhältnis von Wächterdienst, Stechen, Verfolgung
} 
und Reaktionen auf Alarmpheromon bei 2 Bienentypen: bei Europäischen (EHB) und Afrikanisierten Honigbienen (AHB). Zwei Versuche wurden durchgeführt. Der erste Versuch sollte aufzeigen, wie die Reaktionen von AHB und EHB in einem gemischten Volk in Bezug auf Wächterdienst, Stechen und Verfolgung aussehen. Bienenvölker (5000 Bienen) wurden aus EHB und AHB zusammengestellt. Beide Bienentypen stammten aus drei nicht verwandten Ursprungsvölkern. Bienen aus diesen Völkern wurden entsprechend ihrem Ursprungsvolk mit Emailfarbe markiert. Markierte Einzeltiere, die als Wächter beobachtet wurden, erhielten Plättchen mit Nummer, sodass sie individuell erkannt werden konnten. Die Anzahl der Tage, die jede Einzelbiene als Wächterin tätig war, wurde notiert. Die Völker wurden auch auf Stechverhalten getestet. Wir wedelten mit schwarzen Lederflicken oberhalb der Waben. Nach einem Wedeln von $10 \mathrm{~s}$ (mehrere Bienen stachen während dieser Zeit), wurde das erste Lederstück zusammen mit darauf sitzenden Bienen in einen Plastikbeutel getan, und ein anderes Stück wurde sofort für weitere $20 \mathrm{~s}$ geboten. Die Farben der so gefangenen Bienen wurde protokolliert. Danach zogen sich die Beobachter $5 \mathrm{~m}$ zurück und fingen die Bienen, die sie verfolgten bzw umflogen mit dem Netz, um ihre Farben zu bestimmen.

Der 2. Versuch beinhaltete einen Test für das Verteidigungsverhalten der 6 Ursprungsvölker, um das individuelle Verhalten der zusammengesetzten Bienen mit ihrem ganzen Volk zu vergleichen. Die Völker wurden auf ihre Reaktion auf Alarmpheromon getestet, indem Isopentyl Acetat (IPA) in den Volkseingang gegeben wurde. Die Zahl der Bienen vor und direkt nach der Gabe von IPA sowie 20 s später wurde mit Fotos bestimmt. Außerdem wurden die Ursprungsvölker auf ihr Stechverhalten und Verfolgung, wie oben beschrieben, getestet. Zusätzlich untersuchten wir, wie schnell Bienen reagierten und in das schwingende Lederstück vor dem Nesteingang stachen.

Bei den zusammengesetzten Bienen waren es $\mathrm{zu}$ $81 \%$ AHB, die während der ersten 10 s stachen. Aber zwischen 10 und $30 \mathrm{~s}$ waren AHB und EHB zu gleichen Teilen am Stechen beteiligt (Abb. 1, 2). Wenn sie jedoch in ihren einheitlichen Ursprungsvölkern getestet wurden, stachen und verfolgten nur noch 2 der 3 Völker der EHB Typen, ebenfalls auch nur einmal bei den 8 durchgeführten Versuchen, während alle 3 Völker der AHB Typen in allen Versuchen reagierten (Tab. I). Überdies stellten AHB $90 \%$ der Bienen, die die Beobachter während der 18 tägigen Versuchszeit stachen (25\% von ihnen waren gerade vorher als Wächter beobachtet worden). Es ergab sich eine Beziehung bei Verfolgung und Stechen zwischen den 6 Ursprungsvölkern mit dem Verhalten der Einzeltiere als Wächter in den zusammengesetzten Völkern entsprechend ihrer Herkunft (Tab. I).

Die Ergebnisse lassen darauf schließen, dass je verteidigungsbereiter die Bienentypen sind, desto län- ger sind sie Wächterbienen und außerdem scheinen sie die Reaktionsschwelle von weniger verteidigungsbereiten Bienen zu beeinflussen, indem sie sie zum Stechen rekrutieren. Außerdem scheint das individuelle Verhalten bei den unterschiedlichen Aufgaben der Verteidigung Interaktionen zu bewirken, die zu einer erhöhten Reaktion des gesamten Volkes führen.

\section{Apis mellifera / genotypische Effekte / Wächter- dienst / Afrikanisierte Bienen / Verteidigungs- verhalten}

\section{REFERENCES}

Breed M.D., Rogers K.B. (1991) The behavioral genetics of colony defense in honey bees: genetic variability for guarding behavior, Behav. Genet. 21, 295-303.

Breed M.D., Rogers K.B., Hunley J.A., Moore A.J. (1988) A correlation between guard behavior and defensive response in the honey bee, Apis mellifera, Anim. Behav. 37, 515-516.

Breed M.D., Robinson G.E., Page R.E. (1990) Division of labor during honey bee colony defense, Behav. Ecol. Sociobiol. 27, 395-401.

Butler C.G., Free J.B. (1952) The behavior of worker honeybees at the hive entrance, Behaviour 4, 262-292.

Collins A.M., Rinderer T.E., Harbo J.R., Bolten A.B. (1982) Colony defense by africanized and European honey bees, Science 218, 72-74.

Collins A.M., Rinderer T.E., Tucker K.W., Pesante D.G. (1987) Response to alarm pheromone by European and africanized honey bees, J. Apic. Res. 26, 217-223.

Collins A.M., Rinderer T.E., Tucker K.W. (1988) Colony defense of two honey bee types and their hybrids. I. Naturally mated queens, J. Apic. Res. 27, 137-140.

Collins A.M., Rinderer T.E. (1991) Genetics of defensive behavior I, in: Spivak M., Fletcher D.J.C., Breed M.D. (Eds.), The "African" Honey bee, Westview Press, Boulder, CO, pp. 309-328.

Cunard S.J., Breed M.D. (1998) Post-stinging behavior of worker honey bees (Hymenoptera: Apidae), Ann. Entomol. Soc. Am. 91, 754-757.

Free J.B. (1961) The stimuli releasing the stinging response of honey bees, Anim. Behav. 9, 193196.

Ghent R.L., Gary N.E. (1962) A chemical alarm releaser in honey bee stings (Apis mellifera L.), Psyche 69, 1-6.

Giray T., Guzmán-Novoa E., Aron C.W., Zelinsky B., Fahrbach S.E., Robinson G.E. (2000) Genetic variation in worker temporal polyethism and colony defensiveness in the honey bee, Apis mellifera, Behav. Ecol. 11, 44-55.

Guzmán-Novoa E., Page R.E. (1993) Backcrossing Africanized honey bee queens to European 
drones reduces colony defensive behavior, Ann. Entomol. Soc. Am. 86, 352-355.

Guzmán-Novoa E., Page R.E. (1994) Genetic dominance and worker interactions affect honey bee colony defense, Behav. Ecol. 5, 91-97.

Guzmán-Novoa E., Page R.E., Spangler H.G., Erickson E.H. (1999) A comparison of two assays to test the defensive behaviour of honeybees (Apis mellifera), J. Apic. Res. 38, 205-209.

Guzmán-Novoa E., Hunt G.J., Uribe J.L., Smith C., Arechavaleta-Velasco M.E. (2002) Confirmation of QTL effects and evidence of genetic dominance of honey bee defensive behavior: Results of colony and individual behavioral assays, Behav. Genet. 32, 95-102.

Hunt G.J., Guzmán-Novoa E., Fondrk M.K., Page R.E. (1998) Quantitative trait loci for honey bee stinging behavior and body size, Apis mellifica L., Genetics 148, 1203-1213.

Lecomte J. (1963) Le comportement agressif des ouvrières d'Apis mellifica L., Ph.D. thesis, Université de Paris in Ann. Abeille 1961, 4, 165270.

Maschwitz U.W. (1964) Alarm substances and alarm behaviour in social hymenoptera, Nature 204, 324-327.

Moritz R.F.A., Southwick E.E., Harbo J.R. (1987) Maternal and pre eclosional factors affecting alarm behavior in adult honey bees (Apis mellifera L.), Insect Soc. 34, 298-307.

Nielsen D.I., Ebert P.R., Hunt G.J., Guzmán-Novoa E., Kinnee S.A., Page R.E. (1999) Identification of africanized honey bees (Hymenoptera:
Apidae) incorporating morphometrics and an improved polymerase chain reaction mitotyping procedure, Ann. Entomol. Soc. Am. 92, 167-174.

Page R.E., Robinson G.E. (1991) The genetics of the division of labour in honey bee colonies, Adv. Insect Physiol. 23, 117-169.

Paxton R.J., Sakamoto C.H., Rugiga F.C.N. (1994) Modification of honey bee (Apis mellifera L.) stinging behavior by within-colony environment and age, J. Apic. Res. 33, 75-82.

Pickett J.A., Williams I.H., Martin A.P. (1982) (Z)11-eicosen-1-ol, an important new pheromonal component from the sting of the honey bee, Apis mellifera L. (Hymenoptera:Apidae), J. Chem. Ecol. 8, 163-175.

Ribbands C.R. (1954) The defense of the honeybee community, Proc. R. Soc. London B 142, 514 524.

Stort A.C., Gonçalves L.S. (1991) Genetics of defensive behavior II, in: Spivak M., Fletcher D.J.C., Breed M.D. (Eds.), The "African" Honey bee, Westview Press, Boulder, CO, pp. 329-356.

Sylvester H.A., Rinderer T.E. (1987) Fast Africanized bee identification system (FABIS) manual, Am. Bee J. 127, 511-516.

Wager B.R., Breed M.D. (2000) Does honey bee sting alarm pheromone give orientation information to defensive bees? Ann. Entomol. Soc. Am. 93, 1329-1332.

Winston M.L. (1992) The biology and management of Africanized honey bees, Annu. Rev. Entomol. 37, 173-193. 